\title{
PENGARUH KEPEMILIKAN INSTITUSIONAL PADA HUBUNGAN POSITIF ANTARA PROFITABILITAS DAN NILAI PERUSAHAAN
}

\author{
I Ketut Sunarwijaya* \\ Universitas Mahasaraswati Denpasar, Jl. Kamboja No.11A, Denpasar- \\ Bali, Indonesia \\ *(sunarwijaya@ymail.com)
}

\begin{abstract}
ABSTRAK
Tujuan penelitian ini adalah untuk mengetahui pengaruh kepemilikan institusional pada hubungan positif antara profitabilitas dan nilai perusahaan. Penelitian ini dilakukan di Bursa Efek Indonesia pada tahun buku 2013-2015. Metode penentuan sampel menggunakan metode purposive sampling sehingga diperoleh 150 sampel penelitian. Analisis data yang digunakan dalam penelitian ini adalah statistik deskriptif, uji asumsi klasik, dan teknik moderated regression analysis (MRA) yang merupakan aplikasi khusus regresi berganda linear dimana dalam persamaan regresinya menggandung unsur interaksi. Hasil pengujian menunjukkan bahwa nilai Adjusted $\mathrm{R}^{2}$ sebesar 0,231, uji $\mathrm{F}$ memiliki nilai signifikansi sebesar 0,000 , dan uji moderated regression analysis menunjukkan bahwa profitabilitas berpengaruh positif signifikan sebesar 1,392 dengan tingkat signifikansi 0,018 . Sedangkan variabel interaksi (profitabilitas $\mathrm{x}$ kepemilikan institusional) juga berpengaruh positif signifikan sebesar 0,048 dengan tingkat signifikansi sebesar 0,001.
\end{abstract}

Kata kunci: Profitabilitas, kepemilikan institusional, nilai perusahaan

\begin{abstract}
The purpose of this research is to investigate the influence of institutional ownership on the positive relationship between profitability and the company value. The study was conducted on the Indonesia stock exchange in the fiscal year 2013-2014. Method of determination of the sample using the method of purposive sampling so that the retrieved sample 150 research. The analysis of the data used in this research is descriptive statistics, classic assumption test, and moderated regression analysis (MRA) which is a special application of linear multiple regression equations in regresinya begins an element of interaction. The test results show that the value of the Adjusted $R^{2}$ of 0.231 , test $F$ has a value of significance 0.000, and test moderated regression analysis shows that the profitability of a significant positive effect of 0.018 significance level with 1.392. While variable interactions (profitability $x$ institutional ownership) are also positive significant effect of level of significance 0.048 of 0.001 .
\end{abstract}

Keywords: profitability, institutional ownership, company value 


\section{PENDAHULUAN}

Rasio profitabilitas merupakan rasio untuk menilai kemampuan perusahaan dalam mencari keuntungan (Kasmir, 2010). Analisis mengenai profitabilitas ini sangat penting bagi kreditor dan investor. Bagi kreditor, laba merupakan sumber pembayaran bunga dan pokok pinjaman, sedangkan bagi investor, laba merupakan salah satu faktor penentu perubahan nilai efek. Hal yang terpenting bagi perusahaan adalah bagaimana laba tersebut bisa memaksimalkan pemegang saham bukan seberapa besar laba yang dihasilkan oleh perusahaan.

Profitabilitas merupakan suatu indikator kinerja yang dilakukan oleh manajemen perusahaan dalam mengelola kekayaan perusahaan yang ditunjukan oleh laba yang dihasilkan perusahaan. Laba yang dihasilkan perusahaan berasal dari penjualan dan keputusan investasi yang dilakukan perusahaan. Salah satu ukuran kinerja perusahaan yang sering digunakan sebagai dasar pengambilan keputusan adalah laba yang dihasilkan oleh perusahaan. Profitabilitas dapat diartikan sebagai kemampuan perusahaan dalam memperoleh laba. Para investor menanamkan saham pada perusahaan adalah untuk mendapatkan return. Semakin tinggi kemampuan perusahaan memperoleh laba, maka semakin besar return yang diharapkan investor, sehingga menjadikan nilai perusahaan menjadi lebih baik. Ukuran profitabilitas perusahaan dapat berbagai macam seperti: laba operasi, laba bersih, tingkat pengembalian investasi/ aktiva, dan tingkat pengembalian ekuitas pemilik. Rasio profitabilitas menunjukkan keberhasilan perusahaan dalam menghasilkan keuntungan.

Kepemilikan saham oleh institusi dapat memantau secara profesional perkembangan investasinya sehingga tingkat pengendalian terhadap manajemen sangat tinggi yang pada akhirnya dapat menekan potensi kecurangan. Faizal (2004) menyatakan bahwa semakin besar kepemilikan institusional maka semakin efisien pemanfaatan aktiva perusahaan dan diharapkan dapat bertindak sebagai pencegah terhadap pemborosan yang dilakukan oleh manajemen. Shleifer dan Vishny (1986) berpendapat bahwa kepemilikan institusional yang cukup besar akan mempengaruhi nilai pasar perusahaan. Semakin besar tingkat kepemilikan saham institusi maka semakin efektif mekanisme pengendalian terhadap kinerja manajemen. 
Penelitian ini dilakukan untuk menguji kembali hubungan antara kinerja keuangan (profitabilitas) dan nilai perusahaan (Tobin's q). Adanya hasil yang tidak konsisten dari penelitian-penelitian sebelumnya menyebabkan isu ini masih menjadi topik yang penting untuk diteliti. Penelitian ini berbeda dari penelitianpenelitian sebelumnya karena menggunakan corporate governance yang diproksikan dengan menggunakan kepemilikan institusional sebagai variabel pemoderasi. Masalah-masalah corporate governance muncul karena terjadinya pemisahan antara kepemilikan di pihak principal/ investor dan pengendalian di pihak agent/manajer (La Porta et al., 2002) dan (Albuquerque dan Wang, 2007).

\section{Penerapan}

corporate governance yang baik diharapkan dapat meningkatkan nilai perusahaan (Surya dan Yustiavandana, 2006).

Penggunaan corporate governance sebagai variabel pemoderasi dalam penelitian ini diharapkan dapat memperkuat hubungan antara kinerja keuangan dan nilai perusahaan. Harapan dari penerapan sistem corporate governance yang diproksikan dengan kepemilikan institusional adalah tercapainya peningkatan nilai perusahaan. Melalui penerapan sistem corporate governance diharapkan profitabilitas perusahaan akan meningkat menjadi lebih baik, dengan meningkatnya profitabilitas perusahaan diharapkan juga dapat meningkatkan harga saham perusahaan sebagai indikator dari nilai perusahaan.

Berdasarkan latar belakang tersebut, yang menjadi pokok permasalahan dalam penelitian ini adalah: "Apakah kepemilikan institusional berpengaruh pada hubungan positif antara kinerja keuangan dan nilai perusahaan?". Sesuai dengan latar belakang dan rumusan masalah, maka yang menjadi tujuan dalam penelitian ini adalah untuk mengetahui pengaruh corporate governance pada hubungan positif antara kinerja keuangan dan nilai perusahaan.

\section{TELAAH LITERATUR DAN PERUMUSAN HIPOTESIS}

Teori Keagenan

Hubungan keagenan adalah sebuah kontrak antara investor dan agen (Coase, 1937; Jensen dan Meckling, 1976; dan Fama dan Jensen, 1983) dalam Darmawati dkk. 
(2004). Secara ideal, investor dan manajer sebaiknya menandatangani kontrak yang lengkap, yang menspesifikasikan secara tepat apa saja yang akan dilakukan oleh manajer, dan bagaimana laba perusahaan akan dialokasikan. Akan tetapi manajer tidak selalu bertindak sesuai dengan kontrak yang telah disepakati antara investor dan manajer sehingga akan menimbulkan agency problem. Agency problem dapat merugikan investor karena tidak terlibat langsung dalam pengelolaan perusahaan sehingga tidak memiliki akses untuk mendapatkan informasi yang memadai. Aspek corporate governance seperti kepemilikan institusional dipandang sebagai mekanisme kontrol yang tepat untuk mengurangi konflik keagenan (Black et al., 2003).

\section{Profitabilitas}

Rasio profitabilitas merupakan rasio untuk menilai kemampuan perusahaan dalam mencari keuntungan (Kasmir, 2010:115). Analisis mengenai profitabilitas ini sangat penting bagi kreditor dan investor. Bagi kreditor, laba merupakan sumber pembayaran bunga dan pokok pinjaman, sedangkan bagi investor, laba merupakan salah satu faktor penentu perubahan nilai efek. Hal yang terpenting bagi perusahaan adalah bagaimana laba tersebut bisa memaksimalkan pemegang saham bukan seberapa besar laba yang dihasilkan oleh perusahaan. Profitabilitas merupakan suatu indikator kinerja yang dilakukan oleh manajemen perusahaan dalam mengelola kekayaan perusahaan yang ditunjukan oleh laba yang dihasilkan perusahaan. Laba yang dihasilkan perusahaan berasal dari penjualan dan keputusan investasi yang dilakukan perusahaan. Salah satu ukuran kinerja perusahaan yang sering digunakan sebagai dasar pengambilan keputusan adalah laba yang dihasilkan oleh perusahaan.

ROA merupakan salah satu rasio yang mengukur tingkat profitabilitas perusahaan. ROA digunakan untuk mengukur besarnya laba bersih yang dapat diperoleh dari operasional perusahaan dengan menggunakan seluruh kekayaannya (Lujun, 2009), (Adams dan Mehran, 2005) dan (Anwar dan Herwany, 2001). Tinggi rendahnya ROA tergantung pada pengelolaan asset perusahaan yang menggambarkan efisiensi operasional perusahaan. Semakin tinggi ROA semakin efisien operasional perusahaan dan semakin rendah ROA semakin tidak efisien operasional perusahaan, rendahnya ROA dapat disebabkan oleh banyaknya 
investasi/persediaan perusahaan yang mengganggur dan aktiva tetap perusahaan beroperasi di bawah kapasitas normal.

\section{Corporate Governance}

Corporate governance dapat didefinisikan sebagai suatu proses dan struktur yang digunakan oleh organ perusahaan (Pemegang Saham/Pemilik Modal, Komisaris dan Direksi) untuk meningkatkan keberhasilan usaha dan akuntabilitas perusahaan guna mewujudkan nilai pemegang saham dalam jangka waktu panjang dengan tetap memperhatikan keberhasilan stakeholder lainnya, berlandaskan peraturan perundangundangan dan nilai-nilai etika (Sutedi, 2011:1). Forum for Corporate Governance in Indonesia (2001) merumuskan corporate governance sebagai sistem tata kelola perusahaan yang menjelaskan hubungan antara berbagai partisipan dalam perusahaan yang menentukan arah dan kinerja perusahaan. Setiap perusahaan harus memastikan bahwa asas CG diterapkan pada setiap aspek bisnis dan disemua jajaran perusahaan. Asas corporate governance yaitu transparansi, akuntabilitas, responsibilitas, independensi, serta kesetaraan dan kewajaran diperlukan untuk mencapai kinerja yang berkesinambungan dengan tetap memperhatikan pemangku kepentingan (Zarkasyi, 2008:38).

\section{Kepemilikan Institusional}

Kepemilikan institusional adalah besarnya jumlah saham yang dimiliki institusi dari total saham yang beredar. Faizal (2004) menyatakan bahwa semakin besar kepemilikan institusional maka semakin efisien pemanfaatan aktiva perusahaan dan diharapkan juga dapat bertindak sebagai pencegah terhadap pemborosan yang dilakukan oleh manajemen. Laporan keuangan periodik yang diterbitkan manajemen sebagai sumber informasi bagi investor institusi dalam melakukan aktivitas monitoring (Potter, 1991). Shleifer dan Vishny berpendapat bahwa kepemilikan institusional yang cukup besar akan mempengaruhi nilai pasar perusahaan. Semakin besar tingkat kepemilikan saham institusi maka semakin efektif mekanisme pengendalian terhadap kinerja manajemen. Adanya kepemilikan saham institusional dapat memantau secara profesional perkembangan investasinya sehingga tingkat pengendalian terhadap kinerja manajemen sangat tinggi yang pada akhirnya dapat menekan potensi 
kecurangan yang dilakukan oleh manajemen.

\section{Nilai Perusahaan}

Nilai perusahaan adalah harga yang bersedia dibayar calon pembeli apabila perusahaan dijual (Husnan, 2002). Nilai perusahaan dalam penelitian ini didefinisikan sebagai nilai pasar perusahaan karena dapat memberikan kemakmuran bagi investor apabila harga saham meningkat. Salah satu cara untuk menghitung nilai perusahaan dengan menggunakan Tobin's Q yang dikembangkan oleh James Tobin (1967) dalam Darmawati dkk. (2004). Rasio Tobin's Q merupakan harga pengganti dari biaya yang dibutuhkan untuk mendapatkan asset yang persis sama dengan asset yang dimiliki perusahaan. Rasio Q menunjukkan kesempatan bertumbuh perusahaan di masa yang akan datang melalui kebijakan investasinya.

\section{Pengembangan Hipotesis}

HA: Kepemilikan institusional berpengaruh pada hubungan positif antara profitabilitas dan nilai perusahaan.

\section{METODE}

\section{Pemilihan dan Pengumpulan Data}

Populasi dalam penelitian ini adalah seluruh perusahaan manufaktur yang terdaftar di Bursa Efek Indonesia pada tahun 20132015. Sedangkan jumlah sampel dalam penelitian ini adalah sebanyak 150 sampel penelitian yang dipilih dengan metode purposive sampling dengan kriteria berikut ini.

1) Seluruh perusahaan manufaktur yang terdaftar di BEI tahun 2013-2015.

2) Perusahaan mempublikasikan laporan tahunan berturut-turut tahun 2013-2015.

3) Perusahaan memiliki data profitabilitas (ROA), kepemilikan institusional, dan nilai perusahaan.

\section{Pengukuran dan Definisi}

\section{Operasional Variabel Penelitian}

Variabel independen

Variabel independen dalam penelitian ini adalah profitabilitas yang diukur dengan return on asset (ROA). ROA digunakan untuk mengukur besarnya laba bersih yang dapat diperoleh dari kegiatan operasional perusahaan dengan menggunakan seluruh kekayaannya. ROA dihitung dengan rumus:

$$
\text { ROA }=\frac{\text { Laba Bersih Setelah Pajak }}{\text { Total Aktiva }}
$$

\section{Variabel dependen}

Variabel dependen dalam penelitian ini adalah nilai perusahaan yang 
diukur dengan Tobin's Q yang dikembangkan oleh (Chung dan Pruitt, 1994) dan (DaDalt et al., 2002). Rasio Tobin's $Q$ menunjukkan kesempatan bertumbuh perusahaan di masa yang akan datang melalui kebijakan investasinya. Tobin's Q dihitung dengan rumus:

$$
\text { Tobin's } Q=\frac{(\text { MVE }+ \text { Debt })}{\text { TA }}
$$

Keterangan:

MVE: harga penutupan saham akhir tahun buku $\mathrm{x}$ banyaknya saham biasa yang beredar

Debt: hutang jangka pendek - aset lancar + hutang jangka panjang

TA: nilai buku total aset perusahaan

\section{Variabel moderasi}

Variabel moderasi dalam penelitian ini adalah corporate governance yang diproksikan dengan menggunakan variabel kepemilikan institusional. Kepemilikan institusional (KI) adalah besarnya jumlah saham yang dimiliki institusi dari total saham yang beredar. Rumus perhitungan kepemilikan institusional adalah :

$\mathrm{KI}=\frac{\text { (Jumlah Saham Perbankan,Asuransi, Dana Pensiun) }}{\text { Total Jumlah Saham }} \times 100 \%$

\section{Metode Analisis Data}

Statistik deskriptif

Statistik deskriptif memberikan gambaran suatu data yang dilihat dari nilai minimum, nilai maksimum, rata-rata, dan standar deviasi (Ghozali, 2012:19). Statistik deskriptif menggambarkan data yang menjadi sebuah informasi yang lebih jelas dan mudah untuk dipahami.

Uji asumsi klasik

Sebelum model regresi digunakan untuk menguji hipotesis, terlebih dahulu dilakukan pengujian asumsi klasik untuk mengetahui hubungan antara variabel independen, variabel moderasi dan variabel dependen. Uji asumsi klasik yang digunakan dalam penelitian ini adalah: uji normalitas, uji multikolinieritas, uji autokorelasi, dan uji heteroskesdastisitas.

\section{Uji moderated regression analysis}

Uji interaksi atau sering disebut dengan moderated regression analysis (MRA) merupakan aplikasi khusus regresi berganda linear dimana dalam persamaan regresinya menggandung unsur interaksi (Ghozali, 2009:200). Rumus persamaan statistik yang digunakan adalah sebagai berikut:

$\mathrm{NP}=\mathrm{a}+\beta_{1} \mathrm{PR}+\beta_{2} \mathrm{PR} \mathrm{KI}^{*} \mathrm{e}$

Keterangan:

NP : Nilai perusahaan

KK : Profitabilitas

KI : Kepemilikan institusional

a : konstanta

$\beta 1-\beta 2$ : Koefisien regresi

e : standar eror 
Bila pada persamaan tersebut nilai koefisien regresi $\beta 2$ memiliki tingkat signifikansi lebih kecil dari $\mathrm{a}=$ 0,05, maka dapat dikatakan bahwa kepemilikan institusional sebagai variabel pemoderasi yang mempengaruhi hubungan positif antara profitabilitas dan nilai perusahaan

\section{HASIL DAN PEMBAHASAN}

Statistik Deskriptif

Hasil statistik deskriptif (Tabel 1) menunjukkan bahwa:

1) Variabel profitabilitas memiliki nilai minimum sebesar -0,200, nilai maksimum sebesar 0,380 , nilai rata-rata sebesar 0,048 , dan standar deviasi sebesar 0,091 .

2) Variabel interaksi memiliki nilai minimum sebesar $-9,720$, nilai maksimum sebesar 10,600 , nilai rata-rata sebesar 2,472 dan standar deviasi sebesar 3,743.

3) Variabel nilai perusahaan memiliki nilai minimum sebesar $-1,400$, nilai maksimum sebesar 2,400, nilai rata-rata sebesar 0,570, dan standar deviasi sebesar 0,566.

Tabel 1. Statistik Deskriptif

\begin{tabular}{lccccc}
\hline & $\mathrm{N}$ & Minimum & Maksimum & Mean & Std. Deviation \\
\hline PR & 150 & $-0,20$ & 0,38 & 0,0480 & 0,09075 \\
INTER & 150 & $-9,72$ & 10,60 & 2,4718 & 3,74324 \\
NP & 150 & $-1,40$ & 2,40 & 0,4907 & 0,56630
\end{tabular}

Valid N (listwise)

\section{Uji Asumsi Klasik}

\section{Uji Normalitas}

Uji normalitas bertujuan untuk menguji apakah dalam model regresi, variabel pengganggu atau residual memiliki distribusi normal (Ghozali, 2009:147). Model regresi yang baik adalah yang memiliki distribusi normal atau mendekati normal. Metode yang digunakan adalah dengan menggunakan statistik
Kolgomorov-Smirnov. Hasil uji Kolgomorov-Smirnov menunjukkan tingkat signifikansi Unstandardized Residual sebesar 0,078 > 0,05, hal ini berarti nilai residual dalam penelitian ini berdistribusi normal. Hasil uji normalitas dapat dilihat pada Tabel 2 .

Uji Multikolinearitas

Uji multikolinearitas bertujuan untuk menguji apakah 
dalam model regresi ditemukan adanya korelasi antar variabel bebas (Ghozali, 2009:95). Hasil uji multikolinearitas menunjukkan bahwa variabel-variabel dalam penelitian ini memiliki nlai tolerance >
$10 \%$ dan nilai VIF $<10$. Ini menunjukkan bahwa tidak ada multikolinearitas dalam model regresi yang digunakan. Hasil uji multikolinearitas dapat dilihat pada Tabel 3.

Tabel 2. Hasil Uji Normalitas

\begin{tabular}{|c|c|c|c|}
\hline & & & Unstandardized Residual \\
\hline $\mathrm{N}$ & & & 150 \\
\hline \multirow[t]{2}{*}{ Normal Parameters } & $a, b$ & Mean & 0,00000 \\
\hline & & Std. Deviation & 0,49332522 \\
\hline Most Extreme & & Absolute & 0,104 \\
\hline \multirow[t]{2}{*}{ Difference } & & Positive & 0,104 \\
\hline & & Negative & $-0,076$ \\
\hline Kolmogorov-Smirnov Z & & & 1,273 \\
\hline Asymp. Sig. (2-tailed) & & & 0,078 \\
\hline
\end{tabular}

a. Test distribution is normal

b. Calculated from data

Tabel 3. Hasil Uji Multikolinieritas

\begin{tabular}{llccccc}
\hline \multirow{2}{*}{ Model } & \multicolumn{2}{c}{$\begin{array}{c}\text { Unstandardized } \\
\text { Coefficients }\end{array}$} & $\begin{array}{c}\text { Standardized } \\
\text { Coefficients }\end{array}$ & \multicolumn{2}{c}{$\begin{array}{c}\text { Collinearity } \\
\text { Statistics }\end{array}$} \\
\cline { 3 - 7 } & B & Std. Error & Beta & Tolerance & VIF \\
\hline 1 & (Constant) & 0,305 & 0,049 & & & \\
& PR & 1,392 & 0,580 & 0,233 & 0,597 & 1,676 \\
& INTER & 0,048 & 0,014 & 0,318 & 0,597 & 1,676 \\
\hline
\end{tabular}

a. Dependent Variable: NP

Uji Autokorelasi

Uji autokorelasi bertujuan menguji apakah dalam model regresi linear ada korelasi antara kesalahan pengganggu pada periode $\mathrm{t}$ dengan kesalahan pengganggu pada periode t-1 (Ghozali, 2009:99). Hasil uji
Durbin-Watson (DW Test) menunjukkan nilai DW sebesar 1,940 berada di antara du dan 4-du (du < DW $<4-d u$ atau 1,706 < 1,940< 2,294), ini berarti bahwa tidak terjadi autokorelasi positif atau negatif. 
Hasil uji autokorelasi dapat dilihat pada Tabel 4.

Tabel. 4. Hasil Uji Autokorelasi

Model Summary

\begin{tabular}{cccccc}
\hline Model & $\mathrm{R}$ & $\mathrm{R}$ Square & $\begin{array}{c}\text { Adjusted } \mathrm{R} \\
\text { Square }\end{array}$ & $\begin{array}{c}\text { Std. Error of the } \\
\text { Estimate }\end{array}$ & $\begin{array}{c}\text { Durbin- } \\
\text { Watson }\end{array}$ \\
\hline 1 & $0,491^{\mathrm{a}}$ & 0,241 & 0,231 & 0,49667 & 1,940 \\
\hline
\end{tabular}

a. Predictors: (Constant), INTER, PR

b. Dependent Variabel: NP

Uji Heteroskesdasitas

Uji heteroskesdastisitas bertujuan menguji apakah dalam model regresi terjadi ketidaksamaan variance dari residual satu pengamatan ke pengamatan yang lain (Ghozali, 2009:125). Hasil uji Glejser menunjukkan bahwa tidak ada satupun variabel bebas yang signifikan secara statistik mempengaruhi nilai absolut residual, hal ini dapat dilihat dari probabilitas signifikansinya > 5\% sehingga dapat disimpulkan bahwa dalam model regresi tidak terjadi heteroskesdastisitas. Hasil uji heteroskedastisitas seperti yang ditunjukkan pada Tabel 5.

Tabel 5. Hasil Uji Heterokedastisitas

Coefficients ${ }^{a}$

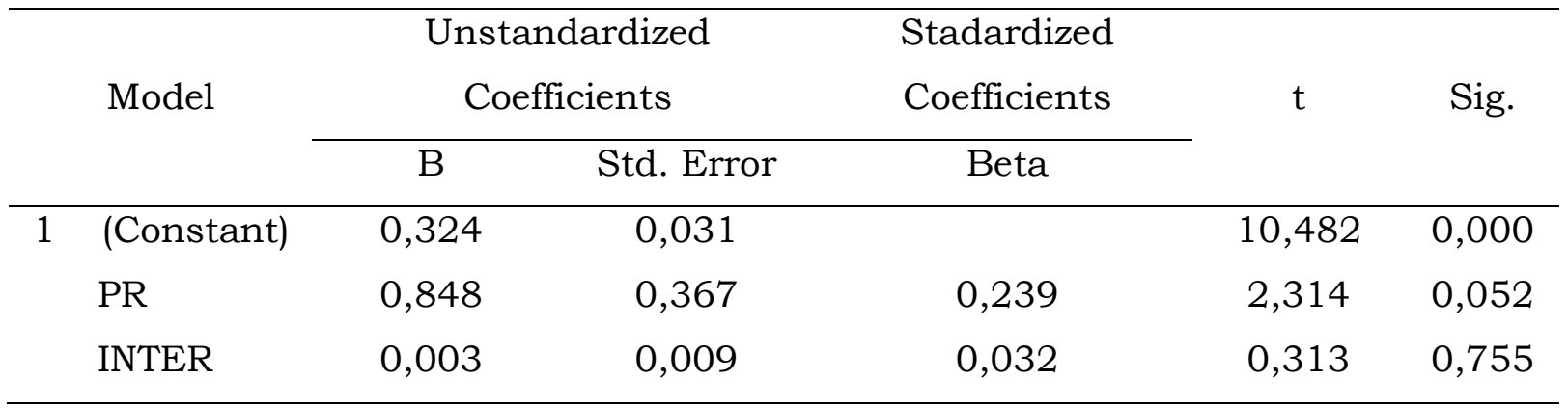

a. Dependent Variable: ABSOLUTE

\section{Moderated Regression Analysis} (MRA)

Moderated regression analysis (MRA) atau uji interaksi merupakan aplikasi khusus regresi berganda linear dimana dalam persamaan regresinya menggandung unsur interaksi. Hasil uji moderated regression analysis mengenai koefisien determinasi, nilai statistik $\mathrm{F}$, dan nilai statistik $t$ seperti yang ditunjukkan pada Lampiran 1. 
Koefisien Determinasi

Koefisien

determinasi

menunjukkan nilai $\mathrm{R}, \mathrm{R}^{2}$, Adjusted $\mathrm{R}^{2}$, dan Standard Error of the Estimate seperti yang dicantumkan pada Tabel 6. Nilai Adjusted $\mathrm{R}^{2}$ sebesar 0,231 menunjukkan bahwa $23,10 \%$ nilai perusahaan dapat dijelaskan oleh variabel profitabilitas dan interaksi antara profitabilitas dan kepemilikan institusional sedangkan sisanya sebesar 76,90\% dijelaskan oleh variabel-variabel lain yang tidak dimasukkan ke dalam model. Nilai Standard Error of the Estimate sebesar 0,497 menunjukkan bahwa semakin kecil nilai Standard Error of the Estimate akan membuat model regresi semakin tepat dalam memprediksi variabel terikat. Hasil uji determinasi dapat dilihat pada Tabel 6 .

Tabel 6. Hasil Uji Koefisien Determinasi

Model Summary ${ }^{b}$

\begin{tabular}{ccccc}
\hline Model & $\mathrm{R}$ & R Square & $\begin{array}{c}\text { Adjusted R } \\
\text { Square }\end{array}$ & $\begin{array}{c}\text { Std. Error of the } \\
\text { Estimate }\end{array}$ \\
\hline 1 & $0,491^{\mathrm{a}}$ & 0,241 & 0,231 & 0,49667 \\
\hline
\end{tabular}

a. Predictors: (Constant), INTER, PR

b. Dependent Variable: NP

\section{Uji Signifikansi Simultan (uji F)}

Uji statistik F menunjukkan pengaruh seluruh variabel independen terhadap variabel dependen. Tabel Anova menunjukkan nilai $\mathrm{F}$ hitung sebesar 23,353 dengan tingkat signifikansi sebesar 0,000. Hasil ini menunjukkan bahwa model regresi tersebut dapat digunakan untuk memprediksi nilai perusahaan, ini berarti bahwa variabel profitabilitas (PR) dan interaksi antara profitabilitas dan kepemilikan institusional (INTER) berpengaruh pada nilai perusahaan. Hasil uji signifikansi simultan (uji f) dapat dilihat pada Tabel 7 .

\section{Uji Signifikansi Parameter \\ Individual (uji t)}

Uji statistik $\mathrm{t}$ menunjukkan seberapa jauh pengaruh satu variabel independen secara individual dalam menerangkan variasi variabel dependen (Ghozali, 2009:88). Hasil uji statistik t ditunjukkan pada Lampiran 1. Uji statistik $t$ menunjukkan pengaruh secara parsial variabel $P R$ dan INTER terhadap NP. Berdasarkan hasil uji statistik $t$ dapat diperoleh koefisien regresi variabel $P R$ dan 
INTER masing-masing sebesar 2,399 dan 3,420. Hasil uji signifikansi parameter individual (uji t) dapat dilihat pada tabel 8 .

Tabel 7. Hasil Uji Signifikansi Simultan (Uji F)

ANOVA $^{b}$

\begin{tabular}{llrrrrr}
\hline \multirow{2}{*}{ Model } & & $\begin{array}{c}\text { Sum of } \\
\text { Squares }\end{array}$ & df & $\begin{array}{c}\text { Mean } \\
\text { Square }\end{array}$ & F & Sig. \\
\hline 1 & Regression & 11,522 & 2 & 5,761 & 23,353 &, $000^{\mathrm{a}}$ \\
& Residual & 36,262 & 147 &, 247 & & \\
& Total & 47,784 & 149 & & & \\
&
\end{tabular}

a. Predictors: (Constant), INTER, PR

b. Dependent Variable: NP

Tabel 8. Hasil Uji Signikansi Parameter Individual (Uji t)

Coefficients $^{a}$

\begin{tabular}{llrrrrr}
\hline \multirow{2}{*}{ Model } & \multicolumn{2}{c}{$\begin{array}{c}\text { Unstandardized } \\
\text { Coefficients }\end{array}$} & $\begin{array}{c}\text { Standardized } \\
\text { Coefficients }\end{array}$ & $\mathrm{t}$ & Sig. \\
\cline { 3 - 5 } & \multicolumn{1}{c}{ B } & Std. Error & Beta & & \\
\hline \multirow{2}{*}{1} & (Constant) &, 305 &, 049 & & 6,225 &, 000 \\
& PR & 1,392 &, 580 &, 223 & 2,399 &, 018 \\
& INTER &, 048 &, 014 &, 318 & 3,420 &, 001 \\
\hline
\end{tabular}

a. Dependent Variable: NP

\section{Pengujian hipotesis}

HA menyatakan bahwa kepemilikan institusional berpengaruh pada hubungan positif antara profitabilitas dan nilai perusahaan. Variabel interaksi antara profitabilitas dan kepemilikan institusional memiliki nilai koefisien regresi sebesar 0,048 dengan tingkat signifikansi sebesar 0,01. Hal ini berarti bahwa kepemilikan institusional berpengaruh positif signifikan terhadap hubungan positif antara profitabilitas dan nilai perusahaan yang sesuai dengan hipotesis penelitian. Berdasarkan hasil moderated regression analysis maka dapat dirumuskan persamaan regresi sebagai berikut.

$$
\mathrm{NP}=\mathrm{a}+1,392 \mathrm{PR}+0,048 \mathrm{PR} * \mathrm{KI}+\mathrm{e}
$$

Gambar 1 menunjukkan model persamaan pengaruh kepemilikan institusional pada hubungan positif antara profitabilitas dan nilai perusahaan. 
$(\beta=1,392 ; a=0,018)$

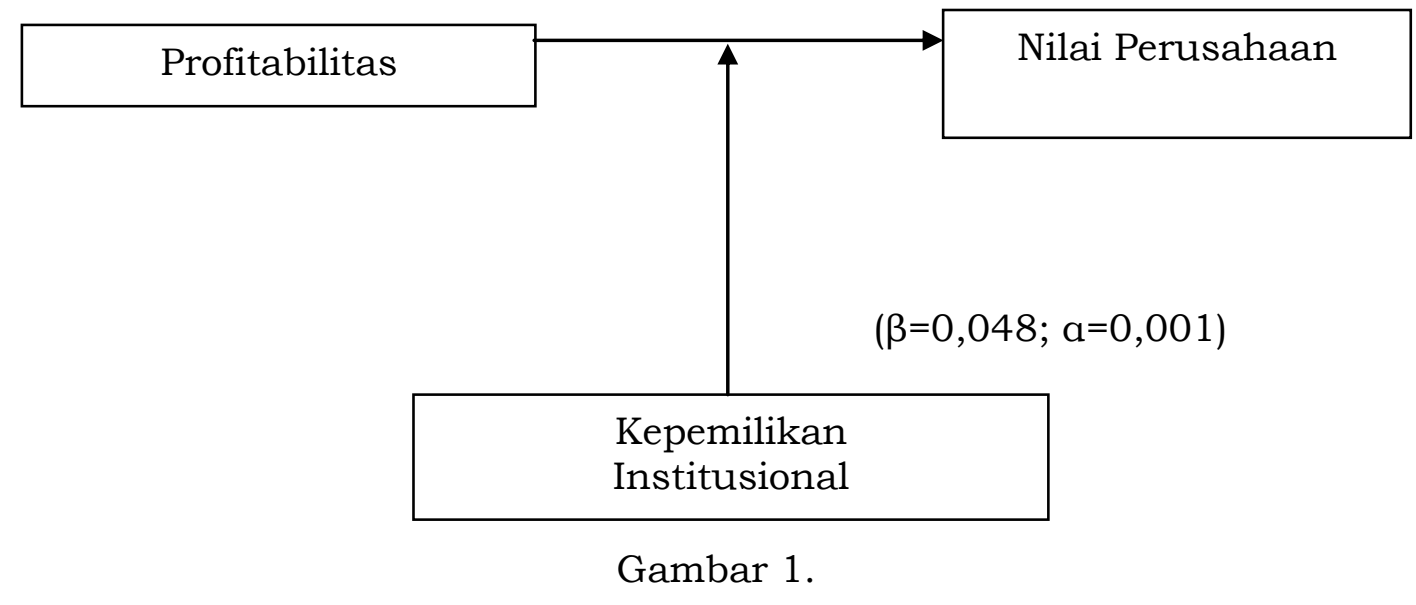

Pengaruh Kepemilikan Institusional Pada Hubungan Positif Antara

Profitabilitas dan Nilai Perusahaan

\section{Pembahasan Hasil Penelitian}

Return on asset (ROA) merupakan salah satu rasio yang mengukur tingkat profitabilitas perusahaan. ROA digunakan untuk mengukur besarnya laba bersih yang dapat diperoleh dari operasional perusahaan dengan menggunakan seluruh kekayaannya. Tinggi rendahnya ROA tergantung pada Miller (1958) menyatakan bahwa nilai perusahaan ditentukan oleh earnings power asset perusahaan. Hasil positif menunjukkan bahwa semakin tinggi earnings power semakin efisien perputaran asset dan semakin tinggi profit margin yang diperoleh perusahaan yang berdampak pada peningkatan nilai perusahaan. Makaryawati (2002) dan Carlson dan Bathala (1997) juga menemukan bahwa ROA berpengaruh positif pada nilai perusahaan. Oleh karena itu, profitabilitas yang diproksikan dengan ROA merupakan salah satu faktor yang berpengaruh pada nilai perusahaan. pengelolaan asset perusahaan yang menggambarkan efisiensi operasional perusahaan. Semakin tinggi ROA semakin efisien operasional perusahaan.

Penelitian yang dilakukan (Razak et al., 2008) dan (Yuniasih dan Wirakusuma, 2007) menemukan hasil bahwa ROA berpengaruh positif pada nilai perusahaan. Modigliani dan Miller (1958) menyatakan bahwa nilai perusahaan ditentukan oleh earnings power asset perusahaan. Hasil positif menunjukkan bahwa semakin tinggi earnings power semakin efisien perputaran asset dan semakin tinggi profit margin yang diperoleh perusahaan yang berdampak pada 
peningkatan nilai perusahaan. Makaryawati (2002) dan Carlson dan Bathala (1997) juga menemukan bahwa ROA berpengaruh positif pada nilai perusahaan. Oleh karena itu, profitabilitas yang diproksikan dengan ROA merupakan salah satu faktor yang berpengaruh pada nilai perusahaan.

Kepemilikan institusional mensyaratkan adanya tata kelola perusahaan yang baik. Tata kelola perusahaan yang baik menggambarkan bagaimana manajemen mengelola asset dan modalnya dengan baik agar menarik para investor. Pengelolaan asset dan modal suatu perusahaan dapat dilihat dari kinerja keuangan yang ada. Jika pengelolaannya dilakukan dengan baik maka secara otomatis akan meningkatkan nilai perusahaan. Menurut Wahyudi dan Pawestri (2006), penyatuan kepentingan pemegang saham, debtholder, dan manajemen yang merupakan pihakpihak yang mempunyai kepentingan terhadap tujuan perusahaan seringkali menimbulkan masalahmasalah (agency problem). Jika perusahaan menerapkan sistem tata kelola perusahaan yang baik, diharapkan kinerja perusahaan tersebut akan meningkat menjadi lebih baik, dengan meningkatnya kinerja perusahaan diharapkan juga dapat meningkatkan harga saham perusahaan sebagai indikator nilai perusahaan.

Pengujian statistik t menunjukkan interaksi antara profitabilitas dan kepemilikan institusional berpengaruh pada nilai perusahaan sebesar 0,048 dengan tingkat signifikansi 0,001. Berdasarkan hasil tersebut dapat dijelaskan bahwa kepemilikan institusional merupakan variabel pemoderasi yang berpengaruh pada hubungan positif antara profitabilitas dan nilai perusahaan. Adanya kepemilikan institusional sebagai variabel pemoderasi dalam penelitian ini mengindikasikan dapat meminimalisasi masalah-masalah keagenan yang pada gilirannya akan memberikan pengaruh pada hubungan positif antara profitabilitas dan nilai perusahaan. Kepemilikan institusional dipandang sebagai mekanisme kontrol yang tepat untuk mengurangi konflik keagenan (Black et al., 2003).

Pembahasan merupakan bagian terpenting dari keseluruhan isi artikel ilmiah. Tujuan pembahasan adalah: Menjawab masalah penelitian, menafsirkan temuan-temuan, mengintegrasikan temuan dari penelitian ke dalam kumpulan pengetahuan yang telah ada dan 
menyusun teori baru atau memodifikasi teori yang sudah ada.

\section{KESIMPULAN, IMPLIKASI DAN KETERBATASAN PENELITIAN}

Berdasarkan pembahasan yang telah diuraikan dapat disimpulkan bahwa kepemilikan institusional berpengaruh pada hubungan positif antara profitabilitas dan nilai perusahaan. Hal ini dapat dilihat dari koefisien regresi sebesar 0,048 dengan tingkat signifikansi 0,001. Ini berarti bahwa kepemilikan institusional berpengaruh pada hubungan positif antara profitabilitas dan nilai perusahaan.

Hasil

$$
\text { penelitian }
$$

ini

menunjukkan

bahwa

meningkatkan kinerja keuangan melalui profitabilitas, manajemen perusahaan juga harus meningkatkan kinerja non keuangan yang berupa tata kelola perusahaan yang baik. Ini berarti bahwa melalui kepemilikan institusional maka akan dapat meningkatkan hubungan positif antara kinerja keuangan dan nilai perusaaan. Beberapa keterbatasan penelitian ini yang perlu menjadi bahan pengembangan pada penelitian selanjutnya. Saran-saran yang dapat disampaikan berdasarkan keterbatasan penelitian ini adalah sebagai berikut:
1) Penelitian ini hanya menggunakan sampel perusahaan manufaktur dengan tiga tahun pengamatan. Penelitian selanjutnya disarankan untuk menambah jumlah sampel dengan memperpanjang periode pengamatan dan memperluas jenis perusahaan agar hasil penelitian lebih dapat digeneralisasi.

2) Penelitian ini menggunakan variabel profitabilitas yang diproksikan dengan return on asset, mekanisme corporate governance yang digunakan adalah kepemilikan institusional. Penelitian selanjutnya agar dapat menambah proksi profitabilitas, mekanisme corporate governance selain kepemilikan institusional dan proksi nilai perusahaan lainnya.

\section{REFERENSI}

Albuquerque, R dan Wang, N. 2007. Agency Conflicts, Investment, and Asset Pricing. Financial Working Paper No. 167/2007. http://ssrn.com.

Black, B. S., Jang, H., dan Kim, W. 2003. Does Corporate Governance Affect Firm Value? Evidence from Korea. http://ssrn.com 
Chung, K. H dan Pruitt, S. W. 1994. A Simple Approximation of Tobin, $\mathrm{s}$ q. Financial Management, Vol. 23, No. 3, Autumn.

Darmawati, D., Khosmiyah., dan Rahayu. 2005. Hubungan Corporate Governance dan Kinerja Perusahaan. Simposium Nasional Akuntansi VII. Denpasar.

Ghozali, I. 2009. Aplikasi Analisis Multivariat dengan Program SPSS, Edisi ke-4. Semarang: Badan penerbit Universitas Diponegoro.

Husnan, S. 2002. Manajemen Keuangan Teori dan Penerapan (Keputusan Jangka Panjang). Buku 1. Edisi 4. Yogyakarta: BPFE.

Kllaper, L. F dan Love, I. 2002. Corporate Governance, Investor Protection, and Performance in Emerging Market. http//ssrn.com.

La Porta, R., Lopez-de-Silanes, F., Shleifer, A., dan Vishny, R. W. 2002. Investor Protection and Corporate Valuation. Journal of Finance No. 57, 1147-1170.

Lujun. 2009. The Relations among Environmental Disclosure, Environmental Performance and Financial Performance: An Empirical Study in China. http//ssrn.com.
Modigliani, F dan Miller, M. H. 1958. The Cost of Capital, Corporation Finance and The Theory of Invesment. The American Economic Review, 261-297.

Munawir. 2001. Analisa Laporan Keuangan. Yogyakarta: Liberty.

Shleifer, A dan Vishny, R.W. 1997. A Survey of Corporate Governance. Journal of Finance 52, hal. 737783.

Surya, I dan Yustiavandana. 2006. Penerapan Good Corporate Governance:Mengesampingkan

Hak-hak Istimewa Demi Kelangsungan Usaha. Jakarta: Penerbit Kencana.

Sutedi, A. 2011. Good Corporate Governance, Edisi kesatu. Jakarta: Sinar Grafika.

Yuniasih, N. W dan Wirakusuma, M. G. 2007. Pengaruh Kinerja Keuangan Terhadap Nilai Perusahaan Dengan Pengungkapan Corporate Social Responsibility dan Good Corporate Governance Sebagai Variabel Pemoderasi. Universitas Udayana, Bali.

Zarkasyi, M. W. 2008. Good Corporate Governance, Edisi ke 1. Bandung: Alfabeta. 